\title{
A study on the intervention scheme to reduce anemia in female adolescences, in Curug, Tangerang
}

\author{
Savitri Sayogo ${ }^{*}$, Sri Sukmaniah Sudardjat ${ }^{*}$, Sumedi Sudarsono ${ }^{\#}$, Riadi Wirawan ${ }^{\dagger}$, Sri Margono $^{\ddagger}$, Lynne Cobiac $^{\S}$
}

\begin{abstract}
Abstrak
Penelitian ini bertujuan untuk menilai suatu cara intervensi dalam menurunkan prevalensi anemia pada kelompok remaja putri. Penelitian dilakukan pada 71 siswi kelas I dan II sekolah lanjutan tingkat pertama. Pengambilan sampel dilakukan dengan cara cluster, dengan kelas sebagai "cluster". Intervensi yang diberikan berupa tablet yang mengandung $200 \mathrm{mg}$ sulfas ferosus dan 0,25 mg asam folat selama 10 hari berturut-turut per bulan dalam jangka 3 bulan berurutan. Ukuran keluaran utama status gizi berupa kadar $H b$, feritin serum dan indeks massa tubuh. Berdasarkan kadar feritin serum dan Hb didapatkan bahwa defisiensi besi terdapat pada $20 \%$ dan aemia defisiensi besi terdapat pada $5.7 \%$ dari subyek penelitian. Setelah pemberian suplementasi, didapatkan kenaikan bermakna baik pada kadar feritin serum maupun $\mathrm{Hb}$. Diperkirakan intervensi ini dapat merupakan strategi alternatif dalam penanggulangan anemia pada remaja putri.
\end{abstract}

\begin{abstract}
This study was undertaken to evaluate the result of an intervention scheme in reducing anemia in female adolescences. The study was carried out in 71 female adolescences (students of the first and second year class, junior high schooll), which were taken using cluster sampling technique, with classes as clusters. The intervention was supplementation of daily pills containing 200 mg sulphate ferrosus and $0.25 \mathrm{mg}$ folic acid for a period of 10 consecutive days monthly for three consecutive months. The supplementation were administered by the teacher at school during school days. Main outcome measure was nutritional status i.e. the level of Hb, serum ferritin as well as Body Mass Index/BMI. Based on serum ferritin and hemoglobin level, around $20 \%$ of the subjects were classified as early state of iron deficiency/ID, while $5.7 \%$ of the subjects suffered from iron deficiency anaemiallDA. After supplementation, the serum level of ferritin, $\mathrm{Hb}$, as well as the BMI showed a significant increase. This intervention seems to be effective as an alternative strategy in reducing anemia in female adolescences.
\end{abstract}

Keywords: Nutritional status, iron pills, ID, IDA

Indonesia still has national nutritional problems. One of the problems is nutritional anemia i.e. iron deficiency anemia (IDA). ${ }^{1}$ Anemia is a condition, characterized by hemoglobin (Hb) level below normal range. ${ }^{2}$ The prevalence of anemia in several, age groups in the community is still high i.e. between $40-60 \%{ }^{3}$

Adolescences, consisting of active individuals with a high growth rate, will determine the quality of man in

\footnotetext{
${ }^{*}$ Department of Nutrition Medicine, Faculty of Medicine University of Indonesia, Jakarta, Indonesia

* Department of Community Medicine, Faculty of Medicine University of Indonesia, Jakarta, Indonesia

${ }^{\dagger}$ Department of Clinical Pathology, Faculty of Medicine University of Indonesia, Jakarta, Indonesia

${ }^{\ddagger}$ Department of Parasitology Medicine, Faculty of Medicine University of Indonesia, Jakarta, Indonesia

${ }^{\S}$ Division of Human Nutrition, CSIRO
}

the future. Therefore it is necessary to assure an optimal growth rate in this group, and special attention should be paid to the health of female adolescences, who are going to become mothers in the future.

There is little information available, however, concerning the iron status in adolescence and the prevalence of IDA.

The main cause of iron deficiency is possibly insufficient intake of iron and low absorption rate. Meanwhile, parasitic diseases caused by worms or malaria parasites, may worsen the situation. ${ }^{4}$ There are also several determinant factors which influence the prevalence of anemia among female adolescences i.e. the economic level and level of education of the parents.

This study aimed to evaluate the anemia intervention model for female adolescence. 
efforts to control worms were already done in elementary schools in the cooperation with the Department of Parasitology, Faculty of Medicine, University of Indonesia.

One group pre and post test design was used for this study. The study was done from January to September 1998. The population was female students of the government junior high school (the $1^{\text {st }}$ and $2^{\text {nd }}$ year class), age 12-15 years. Subjects were taken using cluster sampling technique, with classes as clusters. Sample size was calculated using the formula of sample size for related-test. ${ }^{5}$ The exclution criteria for the subjects of this study were $\mathrm{Hb}$ level below $8 \mathrm{~g} / \mathrm{dL}$.

Each subject was subjected to an intervention scheme. The intervention was supplementation of daily pills containing $200 \mathrm{mg}$ sulphate ferrosus and $0.25 \mathrm{mg}$ folic acid for a period of 10 consecutive days monthly for three consecutive by the teacher at school during school days. The supplementation was done after the elimination of intestinal helminths.

Home visits were done to obtain the data about socio economic status and data on the dietary intake. Furthermore, body weight, height, haemoglobin/Hb, and serum ferritin before and after the intervention were also measured. The $\mathrm{Hb}$ and serum ferritin level were determined using the cyanmeth ${ }^{6}$ and IRMA ${ }^{7}$ by the Department of Clinical Pathology, Medical Faculty, University of Indonesia.

Data analysis was done using the related t-test, using SPSS statistical package for PC. Ethical clearance applied in the study was approved by the Ethical Committee Medical Faculty, University of Indonesia.

\section{RESULTS}

Out of 75 subjects who were selected, 2 were excluded from this study because they did not want to participate, while 2 subjects moved to another class.

\section{Characteristics of the subjects}

The socio-economic characteristic of 71 subjects were as follow: the majority of the educational level of the fathers was intermediate $(63.4 \%)$, while that of the mothers was low (56.4\%). The religion of $90.1 \%$ of the subjects were moslem; $64.8 \%$ of the fathers worked at non government sector, while $70.4 \%$ of the mothers were housewives (Table 1).
The number of the family members was between 6-7 persons. Since there were difficulties to get information about the income, we analyzed the economic level using their monthly expenditure. Using the Biro Pusat Statistik criteria for expenditure, all of the subjects had low economic level.'

Table 2 is an overview of the general characteristics of subjects. Stunting was found in $28 \%$ of cases. Based on $\mathrm{BMI}^{10} 13 \%$ of the subjects were classified underweight; $86 \%$ had normal nutritional status, while obese was found in $1 \%$ of subjects.

Table 3 is an overview of dietary consumption and iron status of the subjects. Further analysis using $2 \mathrm{x}$ 24 hour recall method revealed that nutrient intake was below $80 \%$ of the recommended dietary allowances/RDA. ${ }^{11}$ Compared to the RDA, the intake was $63 \%$ for carbohydrate, $84 \%$ for protein and $91 \%$ for iron respectively. Moreover, the food pattern of most of the subjects showed very little variation; consumption of vegetables and fruits were very rare, as well as the consumption of protein and iron sources. Using food frequency amount method, it was revealed also that the iron intake was very low i.e. 4.7 mg daily ( $28 \%$ of the RDA).

Considering the consumption of food it can be concluded that both in quality and quantity the nutrient intake was not adequate. Furthermore, the proportion of carbohydrate, protein and fat to the total calorie intake were $56.8 \pm 9.0,9.6 \pm 2.3$, and 30.25 (median), respectively. This findings indicated that the subjects did not consume a well balance diet. ${ }^{12}$

\section{Hematologic data}

Based on $\mathrm{Hb}$ and serum ferritin parameters, the subjects were then categoryzed in different iron status. ${ }^{13}$ The distribution is shown in table 3 , where $69.6 \%$ of the subjects were classified as having normal iron status, while iron deficiency was found in $\pm 20 \%$ of the subjects.

\section{Reassessment of other variables}

Before the reassessment of blood and anthropometry parameters, stool examination was done. The result of stool examination will be published in another paper. The results of blood examination and anthropometry measurements were presented in table 4 . 
Table 1. Distribution of study subjects according to socio-economic characteristics $(\mathrm{n}=71)$

\begin{tabular}{|c|c|c|}
\hline Characteristic & Number & $\%$ \\
\hline \multicolumn{3}{|l|}{ Age (year) : } \\
\hline \multirow{2}{*}{\multicolumn{3}{|c|}{$\begin{array}{l}\text { Father }(43.6 \pm 8.1) \\
\text { Mother }(38.2 \pm 5.9)\end{array}$}} \\
\hline & & \\
\hline \multicolumn{3}{|l|}{ Level of education :* } \\
\hline \multicolumn{3}{|l|}{ Father: } \\
\hline$\overline{\text { Illiterate }}$ & 7 & 9.9 \\
\hline Graduated from elementary school & 15 & 21.1 \\
\hline Graduated from junior high school & 15 & 21.1 \\
\hline Graduated from senior high school & 30 & 42.3 \\
\hline Higher than senior high school & 3 & 4.2 \\
\hline \multicolumn{3}{|l|}{ Mother: ${ }^{t}$} \\
\hline$\overline{\text { Illiterate }}$ & 10 & 14.1 \\
\hline Graduated from elementary school & 30 & 42.3 \\
\hline Graduated from junior high school & 16 & 22.5 \\
\hline Graduated from senior high school & 12 & 16.9 \\
\hline Higher than senior high school & 1 & 1.4 \\
\hline \multirow{2}{*}{\multicolumn{3}{|c|}{$\begin{array}{l}\text { Religion: } \\
\text { Father: }\end{array}$}} \\
\hline & & \\
\hline$\overline{\text { Moslem }}$ & 64 & 90.1 \\
\hline Christian & 3 & 4.2 \\
\hline Hindu & 2 & 2.8 \\
\hline Budha & 2 & 2.8 \\
\hline \multicolumn{3}{|l|}{ Mother: } \\
\hline Moslem & 65 & 91.5 \\
\hline Christian & 2 & 2.8 \\
\hline Hindu & 2 & 2.8 \\
\hline Budha & 2 & 2.8 \\
\hline \multicolumn{3}{|l|}{ Occupation :* } \\
\hline \multicolumn{3}{|l|}{ Father: } \\
\hline Non-Government & 24 & 33.8 \\
\hline Enterpreneur & 22 & 31.0 \\
\hline Farmer & 1 & 1.4 \\
\hline Government official & 11 & 15.5 \\
\hline Worker & 7 & 9.9 \\
\hline Retired & 3 & 4.2 \\
\hline Jobless & 2 & 2.8 \\
\hline \multicolumn{3}{|l|}{ Mother $^{\dagger}$} \\
\hline Non-Government & 3 & 4.2 \\
\hline Enterpreneur & 8 & 11.3 \\
\hline Government official & 6 & 8.5 \\
\hline Worker & 2 & 2.8 \\
\hline House-wife & 50 & 70.4 \\
\hline
\end{tabular}

- missing 1 data

${ }^{\dagger}$ missing 2 data 
Table 2. General characteristics of study subjects

\begin{tabular}{lc}
\hline Variables & \\
\hline${\text { Age }(\text { years })^{*}}^{\dagger}$ & $13.60 \pm 1.00$ \\
${\text { Weight }(\mathrm{kg})^{\dagger}}_{\text {Height }(\mathrm{cm})^{\dagger}}{ }^{\dagger}$ & $40.58 \pm 6.45$ \\
B.M.I. $\left(\mathrm{kg} / \mathrm{m}^{2}\right)^{\dagger}$ & $150.24 \pm 5.33$ \\
$\%<5$ th percentile & $26.94 \pm 3.74$ \\
$\% \geq 85$ th percentile & $9(13 \%)$ \\
Stunting $(\%)$ & $1(1 \%)$ \\
$<3^{\mathrm{rd}}$ percentile & $20(28 \%)$ \\
Haemoglobin $(\mathrm{g} / \mathrm{dL})$ & $13.20 \pm 0.96$ \\
Ferritin $(\mathrm{mg} / \mathrm{L})$ & $35.16 \neq(6.13-130.90)$ \\
\hline
\end{tabular}

$* \overline{\mathrm{x}} \pm S D$

${ }^{\dagger}$ One subject was not analysed (obese)

\# Median value

Table 3. The median of the consumption of nutrient and the iron status

\begin{tabular}{|c|c|c|}
\hline Nutrient & \multicolumn{2}{|c|}{$\operatorname{Median}^{\dagger}$} \\
\hline $\begin{array}{l}\text { Energy } \\
\text { Protein } \\
\text { Fe (\% RDA) }\end{array}$ & \multicolumn{2}{|c|}{$\begin{array}{l}65.07(31.5-149.1) \\
54.36(21.77-171.8) \\
39.74(18.39-144.5)\end{array}$} \\
\hline Iron status & $N \neq$ & $\%$ \\
\hline $\begin{array}{l}\text { Normal } \\
\text { Prelatent iron deficiency } \\
\text { Latent iron deficiency } \\
\text { Iron deficiency anemia } \\
\text { Non iron deficiency anemia }\end{array}$ & $\begin{array}{r}48 \\
8 \\
6 \\
4 \\
3\end{array}$ & $\begin{array}{r}69.6 \\
11.6 \\
8.7 \\
5.7 \\
4.5\end{array}$ \\
\hline
\end{tabular}

* Using $2 \times 24$ hours recall method

${ }^{+}$Median value was used (C.O.V. > 20\%)

$\neq$ Missing 2 data

Table 4. Pre and post intervention result

\begin{tabular}{|c|c|c|c|}
\hline Anthropometry parameters & $\begin{array}{c}\text { Before } \\
\text { supplementation } \\
\text { Mean } \pm \mathrm{SD}(\mathrm{mg})\end{array}$ & $\begin{array}{c}\text { After } \\
\text { supplementation }\end{array}$ & $\begin{array}{l}\text { Probability } \\
\text { level }^{*}\end{array}$ \\
\hline Weight (kg) & $40.60 \pm 6.46$ & $42.10 \pm 6.46$ & $0.001(s)$ \\
\hline Height $(\mathrm{cm})$ & $150.00 \pm 5.30$ & $150.80 \pm 5.22$ & $0.001(\mathrm{~s})$ \\
\hline Body Mass Index $\left(\mathrm{kg} / \mathrm{m}^{2}\right)$ & $18.00 \pm 2.31$ & $18.51 \pm 2.36$ & $0.001(\mathrm{~s})$ \\
\hline \multicolumn{4}{|l|}{ Blood examination } \\
\hline $\begin{array}{l}\mathrm{Hb}(\mathrm{g} / \mathrm{dL}) \\
\text { Ferritin }(\mu \mathrm{g} / \mathrm{L})^{\dagger}\end{array}$ & $\begin{array}{c}13.21 \pm 0.96 \\
35.16(6.13-130.90)\end{array}$ & $\begin{array}{c}13.39 \pm 0.83 \\
63.82(13.15-198.00)\end{array}$ & $\begin{array}{c}0.02(\mathrm{~s}) \neq \\
0.01(\mathrm{~s})\end{array}$ \\
\hline
\end{tabular}

* Paired t-test

${ }^{\dagger}$ Median value

\# Wilcoxon match pair tests 


\section{DISCUSSION}

\section{Characteristics of the subjects}

In term of economic level, all of the subjects were classified as having low economic level (Table 1). This condition affects the nutrient intake of the subjects, since they still depend on their family. This situation was worsened by the fact that $56 \%$ of the mothers had low education level. Uneducated mothers lead to inability to absorb informations regarding health, particularly on IDA. On the other hand, mothers have important role on the preparation of meals in the family. Considering this data, we may conclude that most of the subjects could be classified as having low socioeconomic level.

This conclusion is supported by the overview of the general characteristic of the subjects which could be seen in table 2 . The high rate of stunting $(28.2 \%)$ is a manifestation of previous chronic poor health and nutrition condition, which has been regarded as an interplay between nutrient intake and infection in early life. ${ }^{14}$ Nutritional factors are a more likely cause of stunting process than the ethnic or genetic back ground. ${ }^{15}$

\section{Hematologic data}

Iron deficiency refers to a state in which the body iron stores have been depleted, while IDA refers to a hematologic status resulting from iron deficiency. The occurance of IDA implies that body iron stores are severely depleted. ${ }^{16}$

Table 3 shows that from the total sample, $69.6 \%$ of the subjects were normal, non anemic iron deficiency were $20.3 \%$, while the prevalence of IDA was $5.7 \%$. These findings indicate that in this study iron deficiency was still a nutritional problem (26\%). It is obvious that not all anemia is caused by the lack of iron. There were 3 subjects $(4.5 \%)$ who did not meet the criteria of IDA. These subjects showed that the caues of the low $\mathrm{Hb}$ level was due to something else. For example vitamin $B_{6}$ deficiency, vitamin $B_{12}$ deficiency or due to a chronic disease. However, further analysis should be done to determine this kind of anemia.

With regard to iron deficient status, dietary supply has to be taken into consideration. It is known that the dietary supply of iron is determined by 3 main factors: total iron intake, content of heme iron taken and the bioavailability of the non-heme iron. ${ }^{17}$ Before intervention, the percentage of low plasma ferritin is quite high $(26 \%)$. This condition could be caused by the increased physiologic demands for growth, expanding red cell mass, basal loss and menstruation. ${ }^{18}$ At the end of the supplementation, several points could be noted:

1. There were an evident significant increase of both serum ferritin and $\mathrm{Hb}$ level.

2. The increase in weight as well as BMI indicate increased dietary energy intake due to increased appetite attributed to the intake of supplement.

3. The increase in height can be attributed to the normal increase in height of adolescence. Increase in height due to iron supplementation was also observed in preschool children ${ }^{19}$ and school children. ${ }^{20}$

In public health programs, impact evaluation is very important. In this study, after the iron supplementation there was a decrease in the prevalence of iron deficiency. Regarding the food consumption of the subjects it can be concluded that the quality and the quantity were not adequate. On the other hand, prolonged poor $\mathrm{Fe}$ intake combined with increased iron losses due to menstruation may pose as risk factors of anemia. Therefore, iron supplementation as an immediate solution, remains the mainstay in the strategy of controlling iron deficiency/ID and IDA. Supplementation as preventive strategy should also be implemented in this high risk adolescence group (the low socio-economic level). The result of our study showed that the intervention is effective as an alternative strategy of controlling $\mathrm{ID}$ and $\mathrm{IDA}$.

\section{CONCLUSION}

The method of the intervention was effective in reducing anemia as well as the cause of improvement of the nutritional status.

\section{Acknowledgement}

Our gratitude is extended to all who were involved in this study and who made the course of this research pleasant and smooth. Our thanks to the former Rector (Prof. Dr. M.K. Tadjudin) and Rector of the University of Indonesia (Prof. Dr. A.R. Budi Santoso, MD), CSIRO, the Health Officials of Kabupaten Tangerang and Puskesmas Kecamatan Curug, and the teachers and students of the Government Junior High School Curug, for the good cooperation and financial support. 


\section{REFERENCES}

1. Depatemen Kesehatan RI. Profil kesehatan Indonesia. Jakarta: Departemen Kesehatan, 1993; 66-9.

2. World Health Organization. Nutritional anemias. Report of WHO Scientific Group. Geneva: WHO, 1972; 5-10.

3. Kodyat BA, Thaha RA, Minarto. Penuntasan masalah gizi kurang. In: Risalah Widyakarya Pangan dan Gizi VI. Jakarta: LIPI, 1998; 755-66.

4. Mahdin AH, Suhamo D, Husaini YK, Siagian LU, Harahap H, Wijayanti TF, et al. Study nutritional anemia an assessment of information complication for supporting and formulating national policy and program. Jakarta: Departemen Kesehatan, 1989; 11-12.

5. Madiyono I, Purwanto HS. Perkiraan besar sampel. In: Sastroasmoro S, Ismail S, eds. Dasar-dasar metodologi penelitian klinis. Jakarta: Binarupa Aksara, 1995; 194-5.

6. Boehringer Manheim GmBH. Diagnostica Text Combination Haemoglobin. Manheim: Boehringer Manheim GmBH, 1984.

7. Anonymous. Operator's manual K-1000. Kobe: Toa Medical Electronics, 1991.

8. Abidin SA, Rasad R. Pengobatan infeksi nematoda usus dengan mebendazol $500 \mathrm{mg}$ dosis tunggal. Medika 1990; 3: 192 .

9. Biro Pusat Statistik RI. Pengeluaran untuk konsumsi penduduk Indonesia per propinsi. Jakarta: Biro Pusat Statistik, 1996; Buku 3 tabel 2.

10. WHO. Adolescent. In: WHO. Physical status: The use and interpretation of anthropometry. WHO Technical Report Series. Geneva: WHO, 1995; 263-306.
11. Muhilal, Jus'at I, Husaini, Djalal F, Tarwotjo Ig. Angka kecukupan gizi yang dianjurkan. In: Rivai MA, ed Risalah Widyakarya Pangan dan Gizi V. Jakarta: Lembaga Ilmu Pengetahuan Indonesia 1994; 432.

12. Departemen Kesehatan RI. Panduan 13 pesan dasar gizi seimbang. Jakarta: Depkes RI, 1995; 11-4.

13. Wick M, Pinggera W, Lechmann P. Ferritin in iron metabolism, diagnostic strategies. New York: SpringerVerlag, 1991; 1-48.

14. Martorell R, Khan K, Schroeder D. Reversibility of stunting epidemiological findings in children from developing countries. Eur J Clin Nutrition 1994; 48 suppl. 1: S 45-57

15. Karlberg J, Jakl F, Lam B, Low L, Jeung C. Linear growth retardation to three phases of growth. Eur $\mathrm{J}$ Clin Nutrition 1994; 48 suppl. 1: S 25-44.

16. Cook JD, Finch CA. Assessing iron status of a population. Am J Clin Nutrition 1979; 32:21 15-9.

17. De Maeyer EM, Dallman P, Gurney JM, Hallberg L, Sood SK, Srikantia SG. Preventing and controling iron deficiency anemia through primary health care. Geneva: WHO, 1989; 14-5.

18. Dallman $P$. Changing iron needs from birth through adolescence. In: Folmon SJ, Zlotkin S eds. Nutritional anemias. New York: Raven Press, 1992; 29-35.

19. Angeles IT, Schultink W, Matulessy P, Gross R, Sastroamidjojo S. Decreased rate of stunting through iron supplementation. Am J Clin Nutrition 1993; 58: 339-42.

20. Chwang L, Soemantri A, Pollit E. Iron supplementation and physical growth of rural Indonesian children. Am J Clin Nutrition 1988; 47: 496-501. 